\title{
TEKNOLOGI TEPAT GUNA ALAT PLATE SLICER SEBAGAI UPAYA PENINGKATAN KECEPATAN DAN KAPASITAS PRODUKSI PENGRAJIN KERUPUK DI DESA JADDIH KECAMATAN SOCAH KABUPATEN BANGKALAN MADURA
}

\author{
Yuliati $^{1}$, Hadi Santosa ${ }^{2}$, Hartono Pranjoto ${ }^{3}$ \\ ${ }^{1,3}$ Jurusan Teknik Elektro, ${ }^{2}$ Jurusan Teknik Industri \\ Fakultas Teknik, Universitas Katolik Widya Mandala Surabaya
}

email : yuliati@ukwms.ac.id, hadi-s@ukwms.ac.id, pranjoto@ukwms.ac.id

\begin{abstract}
Abstrak
Pengrajin kerupuk banyak dijumpai di Desa Jaddih Kecamatan Socah Kabupaten Bangkalan Madura. Namun sebagian besar peralatan dan proses produksi yang mereka lakukan masih sangat sederhana dan konvensional, khususnya pada proses pengirisan adonan kerupuk ini masih terdapat banyak kendala dan kekurangan. Proses pengirisan gelondong adonan kerupuk masih dilakukan dengan pisau dapur biasa secara manual (di dendeng tipis) sehingga pengirisan gelondong adonan kerupuk memerlukan waktu yang cukup lama $(5 \mathrm{~kg} / \mathrm{jam})$ dengan rata rata produksi $50 \mathrm{~kg} / \mathrm{hari}$ serta cukup sulit untuk mendapatkan ketebalan yang sama dalam tiap pengirisannya $( \pm 1 \mathrm{~mm})$. Sejalan dengan upaya pemberdayaan masyarakat khususnya dalam pemanfaatan teknologi, maka dalam kegiatan Program Kemitraan Masyarakat (PKM) - RISTEKDIKTI ini diterapkan teknologi tepat guna alat plate slicer adonan kerupuk, dimana secara mekanik maupun konsumsi daya listriknya kecil, didukung dengan komponen peralatan elektronik yang kompak, serta cara pengoperasian dan pemeliharaan yang mudah. Pemanfaatan alat plate slicer sistem down disk knife ini mampu mengurangi beban pekerjaan manusia serta dapat meningkatkan kecepatan dan kapasitas produksinya. Teknologi tepat guna alat plate slicer ini memiliki kapasitas pengirisan $\pm 100 \mathrm{~kg} / \mathrm{jam}$ atau $20 \mathrm{kali}$ lipat dibandingkan cara tradisional. Alat ini mampu meningkatkan kecepatan produksi dalam pengirisan adonan gelondong kerupuk dan dilengkapi sistem adjustable ketebalan irisan $\pm 0,2 \mathrm{~mm}-2 \mathrm{~mm}$ dengan tiap kenaikan ketebalan 0,2 mm. Dalam kegiatan PKM ini juga dilakukan pelatihan dan penyuluhan cara pemeliharaan alat serta edukasi tentang strategi dan manajemen pemasaran dalam rangka meningkatkan kecepatan produktifitas dan nilai jual produk.
\end{abstract}

Kata Kunci : Kerupuk, alat plate slicer, edukasi, manajemen

\section{PENDAHULUAN}

Pada umumnya masyarakat Indonesia menyukai kerupuk untuk dikonsumsi sebagai makanan tambahan baik untuk lauk pauk atau sebagai makanan kecil. Faktor utama yang menentukan mutu sebuah kerupuk adalah kerenyahannya (Koswara, 2009). Kerupuk dibuat dalam bahan baku utama dari bahan-bahan yang mengandung pati cukup tinggi dan bahan baku tambahan sebagai pelengkapnya. Bahan baku utama yang digunakan dalam pembuatan kerupuk yaitu bahan yang digunakan dalam jumlah besar dan fungsinya tidak dapat digantikan oleh bahan lainnya. Bahan baku tambahan merupakan bahan pelengkap dari bahan baku utama dalam proses produksi kerupuk. Bahan baku utama dalam pembuatan kerupuk adalah bahan-bahan berpati, 
misalnya tepung tapioka, tepung sagu, tepung terigu atau tepung beras, atau nasi. Berbagai jenis kerupuk berdasarkan jenis bahan baku utamanya antara lain kerupuk singkong, kerupuk udang, kerupuk kulit, kerupuk gendar/beras atau biasa disebut kerupuk puli (lempeng).

Secara garis besar proses pembuatan kerupuk adalah sebagai berikut : penyiapan dan pencampuran bahan adonan (tepung, gula, garam, bahan penunjang, seperti singkong, zat pewarna makanan), pembentukan adonan menjadi gelondong, pemasakan gelondong adonan (perebusan/pengukusan), pendinginan, pengirisan gelondong menjadi kepingan tipis kerupuk, pengeringan kerupuk dan penggorengan. Karekteristik gelondong adonan kerupuk mempunyai sifat lengket, kenyal dan sedikit keras membuat proses pengirisannya memerlukan waktu yang lama, dan sulit mendapatkan ketebalan yang sama (Gambar 1).

Pengrajin kerupuk banyak dijumpai di
Desa Jaddih Kecamatan Socah Kabupaten Bangkalan Madura. Namun peralatan dan proses produksi yang mereka lakukan sebagian besar masih bersifat sederhana dan konvensional. Proses pengirisan gelondong adonan kerupuk ini masih terdapat banyak kendala dan kekurangan. Proses pengirisan adonan kerupuk masih dilakukan dengan pisau dapur biasa secara manual satu per satu sehingga menyebabkan kelelahan bagi pengrajin, memerlukan waktu yang cukup lama serta cukup sulit untuk mendapatkan ketebalan yang sama dalam tiap pengirisannya $( \pm 1 \mathrm{~mm})$. Ketebalan irisan berpengaruh nyata terhadap tekstur, rendemen, dan kadar air kerupuk yang dihasilkan. (Sugito dkk), 2013).

Sebagai gambarannya, untuk gelondong kerupuk $5 \mathrm{~kg}$, mereka memerlukan waktu pengirisan dengan cara didendeng selama \pm 1 jam menggunakan pisau dapur seperti tampak pada Gambar 2, padahal dalam sehari mereka mampu memasak $50 \mathrm{~kg}$ gelondong adonan kerupuk sehingga mereka mengeluhkan lamanya waktu proses pengirisan serta menyebabkan kelelahan pada tangan dan punggung disebabkan proses pengirisan manual dengan posisi punggung membungkuk dan tidak ergonomis.

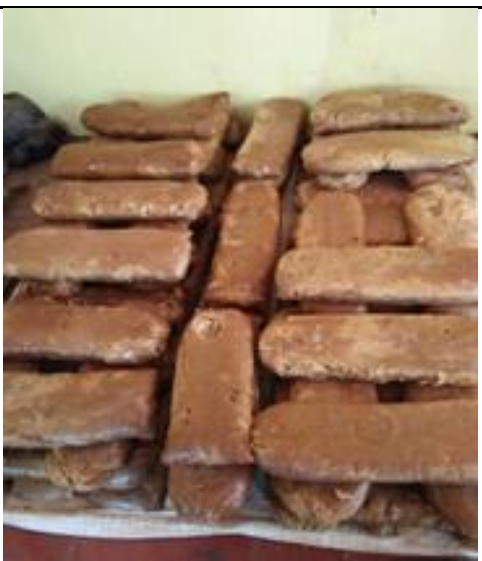

(a)

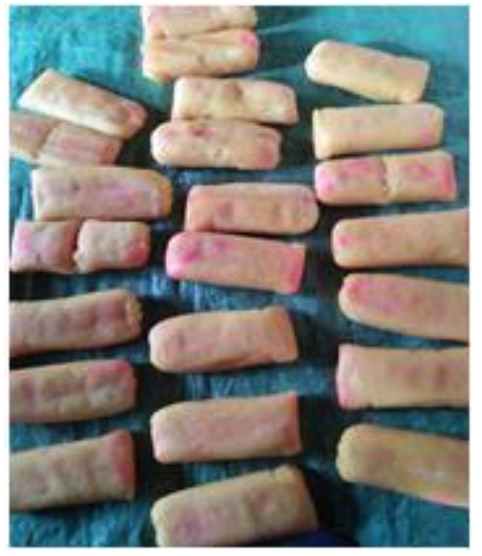

(b)

Gambar 1. Gelondong adonan kerupuk (a) Puli , (b) Singkong

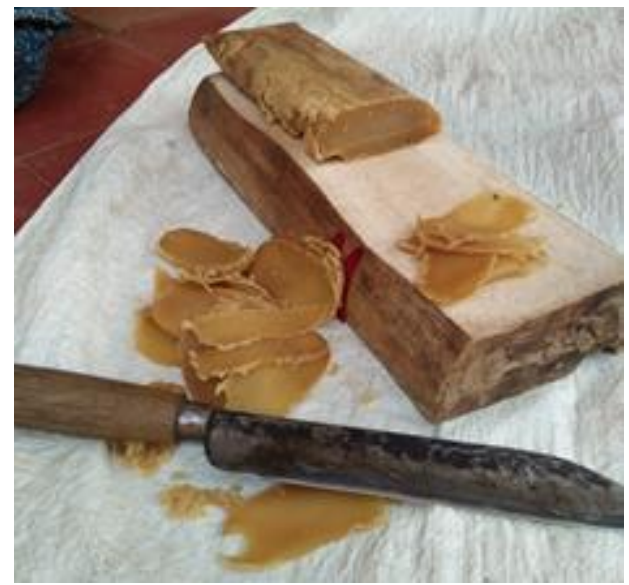

Gambar 2. Pisau dapur sebagai alat pengiris gelondong kerupuk sederhana

Dari segi manajemennya, para pengrajin kerupuk masih menggunakan manajemen Teknologi Tepat Guna 
konvensional dimana mereka biasanya menjual kepada para tengkulak dengan harga yang rendah, tidak melakukan pencatatan dan pembukuan penjualan dengan baik. Mereka juga belum memperhatikan higienitas proses produksi serta masih menggunakan pewarna buatan yang berbahaya bagi kesehatan.

Penelitian pendahuluan telah berhasil dibuat antara lain : Perancangan Alat Bantu Pemotong Kerupuk ( Hadi Santosa, Martinus Edi S, Ardy Wiendarto, 2012), prototype alat pengering kerupuk dan Ikan berbasis Efek Rumah Kaca (Hadi Santosa, Yuliati, 2013), Slicer Elektrik Perajang EmponEmpon (Hadi Santosa, Yuliati, 2010). Lebih lanjut, berdasarkan survei awal, analisis situasi dan permasalahan yang dijumpai pengrajin serta melihat adanya potensi para pengrajin usaha kecil kerupuk di Desa Jaddih Kecamatan Soyah Kabupaten Bangkalan Madura, maka pada program kemitraan masyarakat ini akan dilakukan upaya pemanfaatan alat teknologi tepat guna mesin plate slicer gelondong adonan kerupuk untuk lingkup usaha kecil kelompok pengrajin di Desa Jaddih Kecamatan Socah Kabupaten Bangkalan Madura guna meningkatan kecepatan produksi kerupuk serta kegiatan pelatihan, penyuluhan tentang bagaimana manajemen produksi dan strategi pemasaran yang baik dan benar. Alat teknologi plate slicer tepat guna ini dimaksudkan untuk lingkup usaha kecilmenengah, yang hemat energi dan mudah pemeliharaannya. Dengan pemanfaatan alat plate slicer diharapkan proses pengirisan gelondong adonan kerupuk dapat ditingkatkan kecepatannya, produktivitasnya dan kualitasnya dengan manajemen produksi yang tertata dengan baik, dan pada gilirannya mampu meningkatkan kesejahteraan keluarga sehingga pada akhirnya dapat menunjang ketahanan pangan bagi bangsa .

\section{METODE}

Metode pelaksanaan kegiatan program kemitraan masyarakat ini terbagi dua kegiatan :

1. Tahap proses pembuatan alat plate slicer gelondong adonan kerupuk Pelaksanaannya meliputi kegiatan sebagai berikut :

a. Pekerjaan desain konstruksi alat yang diawali dengan pembuatan gambar teknik meliputi rancangan mekanik dan rancangan listriknya.

b. Penentuan bahan-bahan teknik pendukung alat plate slicer .

c. Pengerjaan dan supervisi di bengkel serta perakitan peralatan dan sistem electric wiring nya.

d. Kegiatan monitoring dan supervisi pekerjaan dalam pembuatan dan perakitan alat plate slicer gelondong adonan kerupuk baik sistem mekanik maupun elektriknya, dilakukan tiap satu sampai dua minggu sekali ke beberapa bengkel permesinan.

2. Tahap implementasi, sosialisasi dan pelatihan kepada masyarakat tentang cara pengoperasian dan pemeliharaan alat pengirisan menggunakan alat plate slicer gelondong adonan kerupuk.

a. Pembuatan modul bagi peserta pelatihan dengan sasaran para pengrajin usaha kecil menengah kerupuk.

b. Pembuatan modul cara pengoperasian alat serta bagaimana cara pemeliharaannya.

c. Kunjungan ke mitra pengrajin kerupuk puli dan kerupuk singkong. Kunjungan ke mitra ini bertujuan untuk menggali informasi dan mengidentifikasi kebutuhan pengrajin sebagai masukan dalam perancangan dan pembuatan alat plate slicer agar sesuai dengan kebutuhan pengguna seperti ditunjukkan pada Gambar 3 .

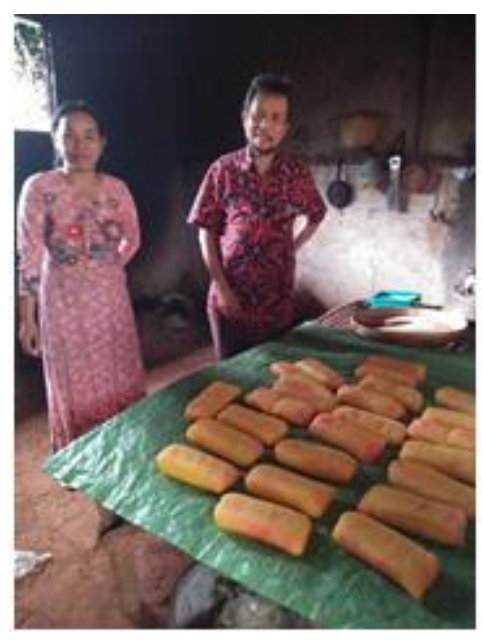

Teknologi Tepat Guna

334 
(a)

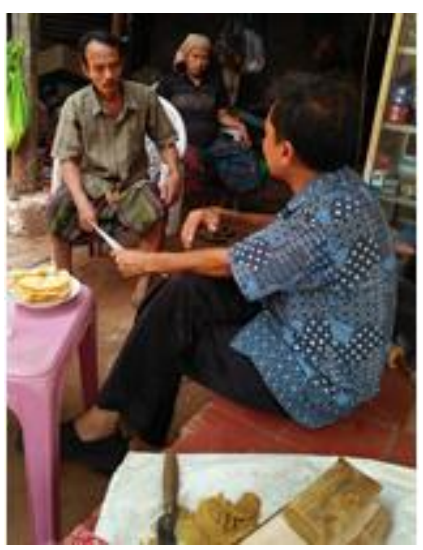

(b)

Gambar 3. Kunjungan ke mitra

d. Demo implementasi alat di Desa Jaddih Kecamatan Socah Bangkalan Madura beserta masyarakat dan para pelaku wirausaha kecil kerupuk. Alat plate slicer yang telah berhasil dibuat diuji coba langsung oleh pengrajin kerupuk untuk melihat unjuk kerja alat seperti ditunjukkan pada Gambar 4.

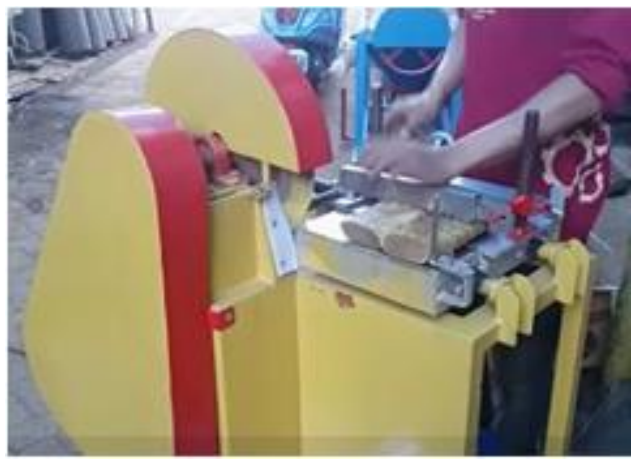

Gambar ..Uji Coba Alat

Dari uji coba alat oleh pengrajin menggunakan kerupuk puli maupun kerupuk singkong, mereka menyatakan bahwa alat plate slicer ini sesuai dan berteknologi tepat guna dan dapat mempercepat serta mempermudah proses pengirisan gelondong adonan kerupuk. Kecepatan proses pengirisan naik dua puluh kali lipat dibandingkan ketika mereka menggunakan cara manual dengan pisau dapur sebagai alat pengirisannya. Hasil pengirisan gelondong adonan kerupuk juga dapat terjaga kualitasnya dari segi fisik maupun tekstur kerupuk serta pengaturan ketebalannya yang mudah yaitu adjustable antara \pm $0,2 \mathrm{~mm}-2 \mathrm{~mm} \mathrm{~mm}$ yang dapat disesuaikan dengan kebutuhan mereka serta hasil irisan yang seragam dan lebih rapi tidak berserabut.

Dengan peningkatan kecepatan proses pengirisan, mutu ketebalan hasil pengirisan yang seragam, maka penggunaan alat teknologi tepat guna ini merupakan alternatif solusi di dalam proses pengirisan gelondong adonan kerupuk menjadi lebih efektif dan efisien dan memperbaiki proses dan kualitas hasil pengirisan gelondong kerupuk.

3. Pembuatan modul pelatihan dan penyuluhan guna edukasi tentang perbaikan manajemen dan strategi pemasaran/ penjualan. Pengrajin diberikan penyuluhan tentang prospek bisnis usaha kecil kerupuk khususnya dalam pemanfaatan media online seperti melalui tokopedia, bukalapak, facebook maupun dalam grup media social yang lain. Saat ini mereka masih menjual di lokal Bangkalan dan sekitarnya yaitu di pasar tradisional, warung maupun pembeli yang datang langsung ke pengrajin kerupuk.

\section{HASIL DAN PEMBAHASAN}

\section{Analisa Situasi dan Permasalahan Mitra}

Prinsip utama tahap pembuatan kerupuk puli maupun kerupuk singkong adalah : penyiapan adonan (tepung, gula, garam, bahan penunjang, serta zat pewarna makanan (opsional), pembentukan adonan menjadi gelondong, pemasakan gelondong adonan, pendinginan gelondong kerupuk sebelum pengirisan, pengirisan gelondong menjadi kepingan tipis kerupuk, pengeringan kerupuk dan penggorengan. Namun khusus untuk produk kerupuk mentah cukup sampai pada proses pengeringan dan kemudian dijual dalam bentuk kerupuk mentah dalam satuan kilogram.

Dalam survei awal kegiatan PKM ini, mitra pengrajin kerupuk puli dan kerupuk singkong di Desa Jaddih Kecamatan Socah Kabupaten Bangkalan berkontribusi dalam memberikan informasi dalam proses pembuatan kerupuk serta pengalaman dan kendala- kendala yang mereka jumpai dalam proses produksi kerupuk seperti ditunjukkan pada Gambar 5.

$$
\text { Teknologi Tepat Guna }
$$


Mereka masih menggunakan pisau dapur dalam pengirisan adonan kerupuk, posisi badan punggung membungkuk, sehingga mengakibatkan mereka mengalami kelelahan dalam proses pengirisan adonan kerupuk karena memerlukan waktu yang lama. Gelondong kerupuk yang memilik tekstur tebal, kenyal dan liat (ductile) menyebabkan hasil irisan berserabut, tidak rapi, dan ketebalan hasil irisan kerupuk tidak sama dan sangat tergantung pada keahlian manusia. rata Permasalahan mitra yang dijumpai adalah mereka rata rata produksi kerupuk puli dan kerupuk singkong adalah 50 $\mathrm{kg} / \mathrm{hari}$ dengan kecepatan proses pengirisan gelondong adonan kerupuk manual $\pm 5 \mathrm{~kg} / \mathrm{jam}$ sehingga pengguna sering merasakan kelelahan, hasil irisan tidak homogen dan tidak rapi serta belum adanya manajemen dan strategi pemasaran yang baik.

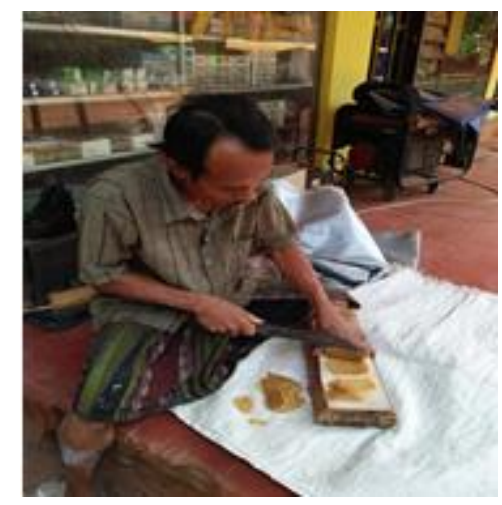

Gambar 5. Mitra Pengrajin Kerupuk

\section{Solusi yang Ditawarkan}

Solusi yang ditawarkan dalam kegiatan PKM pengabdian kepada masyarakat ini adalah :

1. Pembuatan dan pemanfaatan alat plate slicer pada pengirisan adonan kerupuk ikan dengan harga terjangkau oleh daya beli masyarakat, hemat energi dan pemeliharaan yang relatif mudah bagi pengguna.

2. Hasil keluaran lebih unggul daripada dengan cara tradisional manual saja, bersifat hygienis dan konsisten proses produksinya.

3. Percepatan proses pengirisan adonan kerupuk puli dan kerupuk singkong pada Gambar 6 guna meningkatkan kecepatan dan produktivitas pengrajin kerupuk di Desa Jaddih Kecamatan Socah Bangkalan Madura.

4. Teknologi tepat guna di implementasikan dan disosialisasikan kepada masyarakat usaha kecil mikri produsen kerupuk di Desa Jaddih Kecamatan Socah Bangkalan Madura dalam bentuk demo peralatan, pelatihan, penyuluhan serta pelatihan tentang cara mengoperasikan dan pemeliharaan alat, edukasi tentang manajemen dan strategi penjualaan untuk meningkatkan pendapatan para pengrajin.

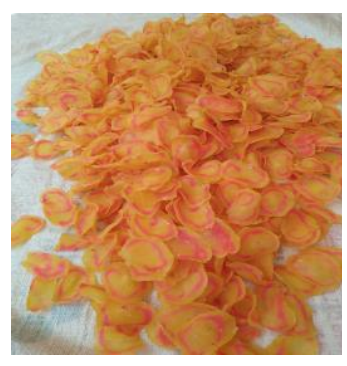

(a)

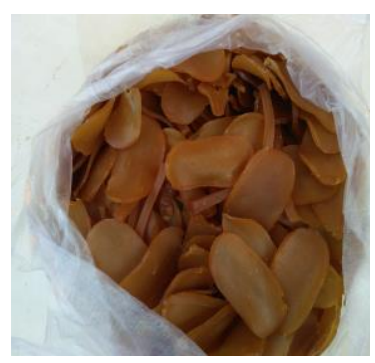

(b)
Gambar 6 (a) Kerupuk singkong ,

(b) Kerupuk Puli

Alat plate slicer sistem down disk knife ini memilik adjuster ketebalan pengirisan kerupuk yang dapat disesuaikan dengan kebutuhan pengrajin $\pm 0,2 \mathrm{~mm}-2 \mathrm{~mm}$ dengan tiap kenaikan ketebalan $0,2 \mathrm{~mm}$. Perancangan alat plate slicer menggunakan satu motor listrik yang berfungsi ganda baik sebagai penggerak maupun adjuster untuk mengatur ketebalan irisan kerupuk.

\section{Kapasitas Alat Plate Slicer Gelondong Kerupuk}

Berdasarkan analisa situasi dan identifikasi kebutuhan mitra, maka rancang bangun alat plate slicer yang telah berhasil dibuat ditunjukkan pada Gambar 7 dan mempunyai spesifikasi sebagai berikut:

1. Dimensi Alat : panjang $=1 \mathrm{~m}$; lebar $=0,5 \mathrm{~m}$; tinggi $=1 \mathrm{~m}$

2. Kapasitas Alat tiap satu kali proses adalah 100 $\mathrm{kg} / \mathrm{jam}$ gelondong adonan kerupuk

$$
\text { Teknologi Tepat Guna }
$$


3. Rangka dan penampung koro pedang berbahan karbon steel

4. Tempat gelondong adonan kerupuk (table) penampung berbahan Stainless Steel 316 food grade.

5. Mesin penggerak menggunakan motor listrik 1/2 HP dengan putaran motor yang direduksi menggunakan gear box

6. Dinding samping bagian atas dan atap terbuat dari Stainless Steel 316

7. Sistem putaran pengupasan menggunakan belt yang putarannya direduksi menggunakan dua rangkaian belt

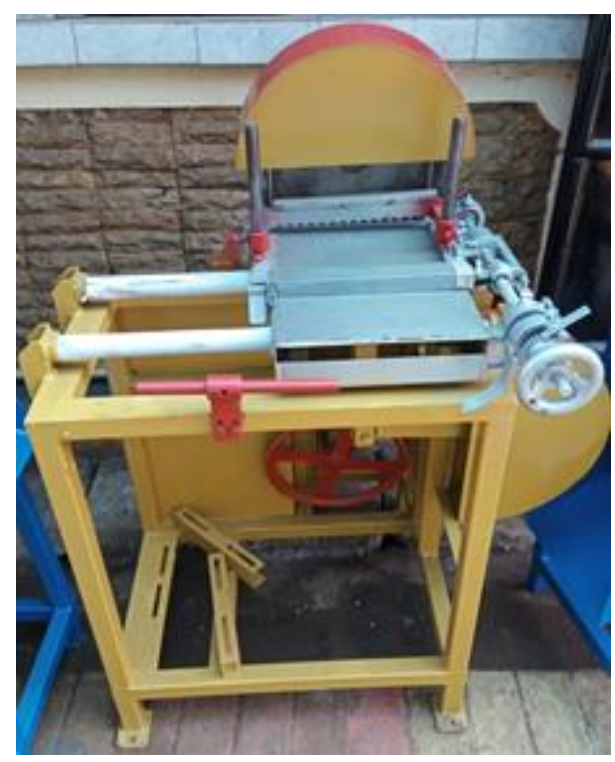

Gambar 7. Alat plate slicer

\section{Hasil Uji Coba Proses Pengirisan Gelondong Kerupuk}

Dimensi gelondong kerupuk adalah berat tiap gelondong kerupuk $\pm 1 \mathrm{~kg}$, panjang $30 \mathrm{~cm}$, lebar 15 $\mathrm{cm}$ dan diameter ketebalan tebal $2 \mathrm{~cm}$. Dalam sekali proses pengirisan dapat diletakkan dua buah gelondong kerupuk d iatas meja (table) penampung. Sistem down disc knife pada alat ini didesain sedemikian hingga langkah pengumpanan gelondong adonan kerupuk sama dan serentak dengan putaran disc knife yang berputar searah jarum jam. dilengkapi dengan sistem pengaturan ketebalan pengirisan (adjustable) $\pm 0,2 \mathrm{~mm}-2 \mathrm{~mm}$ dengan kenaikan ketebalan setiap 0,2 mm sehingga mampu mengatur 10 variasi ketebalan kerupuk.
Hasil pengujian alat mendapatkan haril rata rata tiap dua kilogram gelondong sekali proses di table penampung memerlukan waktu satu menit (60 detik) atau kecepatan sekali proses adalah 2 $\mathrm{kg} / \mathrm{menit}$, Hasil pengirisan lebih rapi, tidak berserabut, serta ketebalannya homogen sesuai dengan pengaturan ketebalan yang dibutuhkan sesuai pesanan pelanggan kerupuk seperti ditunjukkan pada Gambar 8.

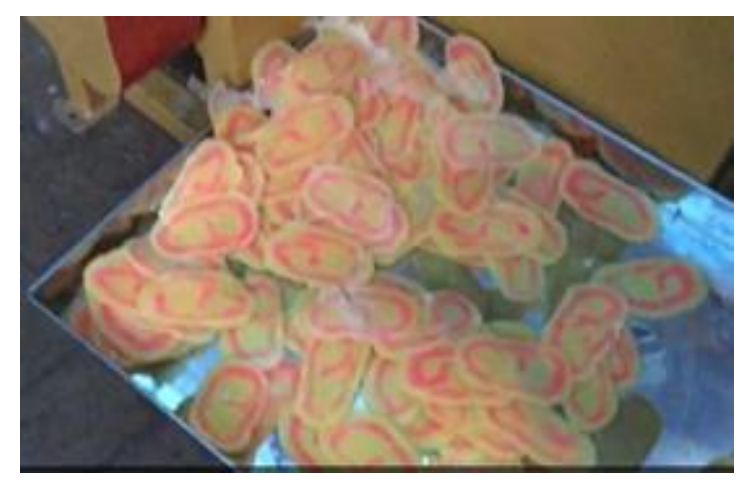

Gambar 8. Hasil Pengirisan Gelondong Kerupuk

\section{Hasil Pengujian Fungsional Bagian Alat Plate Slicer}

Pengujian fungsional bertujuan untuk mengetahui dan melakukan pengamatan apakah setiap komponen/bagian dari alat plate slicer dengan sistem down disk knife ini telah bekerja dengan baik sesuai target yang ditetapkan. Hasil pengamatan menunjukkan bahwa setiap komponen/bagian baik dari sistem mekanik maupun elektrik, sistem motor penggerak, bagian pisau pengirisnya telah dapat berfungsi dengan baik dan stabil hasil pengirisannya. Hasil pengirisan gelondong lontong dapat teriris sempurna, rapi, konsisten ketebalannya sesuai pengaturan yang diberikan, dan teriris $100 \%$. .

\section{Target Luaran}

Pada kegiatan program kemitraan masyarakat ini, target yang dicapai antara lain adalah : 
1. Adanya perubahan proses pengirisan adonan kerupuk dari bersifat tradisional dengan cara mengiris menggunakan pisau dapur biasa yang memerlukan waktu lama menjadi lebih singkat proses pengirisannya serta lebih hygienis.

2. Peningkatan efektifitas dan produktivitas pengirisan adonan kerupuk yang semula dilakukan oleh tenaga manusia selanjutnya manusia berperan sebagai operator mesin.

3. Menciptakan budaya bersih dan sehat bagi masyarakat usaha kecil kerupuk di Desa Jaddih Kecamatan Socah Bangkalan Madura.

5. Penyuluhan serta pelatihan tentang cara mengoperasikan dan pemeliharaan alat, edukasi tentang manajemen dan strategi penjualan untuk meningkatkan pendapatan para pengrajin.

Adapun luaran dalam kegiatan pengabdian masyarakat PKM ini adalah adanya nilai tambah dari sisi teknologi tepat guna yaitu :

1. publikasi pada seminar nasional di prosiding/jurnal

2. Pemanfaatan alat berteknologi tepat guna berupa alat plate slicer gelondong adonan kerupuk ini dirancang dan dibangun dengan harga terjangkau oleh daya beli masyarakat pelaku usaha kecil kerupuk, hemat energi dan pemeliharaan yang relatif mudah bagi pengguna serta bersifat ergonomis. Kapasitas pengirisan adonan kerupuk ikan dapat meningkat 20 kali apabila dibandingkan dengan cara tradisional. Biaya pemeliharaan rendah dan pengoperasian alat mudah.

3. Pelatihan dan edukasi tentang perbaikan manajemen dan strategi pemasaran/ penjualan .

4. Draft pendaftaran paten sederhana.

Adapun Target Capaian Luaran Kegiatan dapat ditunjukkan pada Tabel 1.

\section{Tabel 1 Target Capaian Luaran Kegiatan}

\begin{tabular}{|l|c|l|}
\hline No & Jenis Luaran & $\begin{array}{l}\text { Indikator } \\
\text { Capaian }\end{array}$ \\
\hline \multicolumn{2}{|c|}{ Luaran Wajib } \\
\hline
\end{tabular}

\begin{tabular}{|c|c|c|}
\hline 1 & $\begin{array}{l}\text { Publikasi ilmiah pada Jurnal } \\
\text { ber ISSN/Prosiding jurnal } \\
\text { Nasional }\end{array}$ & Published \\
\hline 2 & $\begin{array}{l}\text { Publikasi pada media masa } \\
\text { cetak/online/repocitory PT }\end{array}$ & $\begin{array}{l}\text { Sudah } \\
\text { terbit }\end{array}$ \\
\hline 3 & $\begin{array}{l}\text { Peningkatan daya saing } \\
\text { (peningkatan kualitas, } \\
\text { kuantitas, serta nilai tambah } \\
\text { barang, jasa, diversifikasi } \\
\text { produk, atau sumber daya } \\
\text { lainnya ) }\end{array}$ & Penerapan \\
\hline 4 & $\begin{array}{l}\text { Peningkatan penerapan iptek } \\
\text { di masyarakat (mekanisasi, } \\
\text { IT, dan manajemen) }\end{array}$ & $\begin{array}{l}\text { Besar } \\
\text { Peningkatan }\end{array}$ \\
\hline 5 & $\begin{array}{l}\text { Perbaikan tata nilai } \\
\text { masyarakat (seni budaya, } \\
\text { sosial, politik, } \\
\text { keamanan,ketentraman, } \\
\text { pendidikan, kesehatan) }\end{array}$ & ada \\
\hline \multicolumn{3}{|c|}{ Luaran Tambahan } \\
\hline 1 & $\begin{array}{l}\text { Jasa; rekayasa sosial, metode } \\
\text { atau sistem, produk/barang }\end{array}$ & Produk \\
\hline 2 & Inovasi baru TTG & Penerapan \\
\hline 3 & \begin{tabular}{lr} 
Hak kekayaan & intelektual \\
(Paten, Paten sederhana, Hak \\
Cipta, Merek dagang, Rahasia \\
dagang, Desain & Produk \\
Industri, & Perlindungan \\
Varietas & Tanaman, \\
Perlindungan & Desain \\
\multicolumn{2}{l}{ Topografi Sirkuit Terpadu) } \\
\end{tabular} & $\begin{array}{l}\text { Draft Paten } \\
\text { Sederhana }\end{array}$ \\
\hline
\end{tabular}

\section{KESIMPULAN}

Pelaksanaan kegiatan Program Kemitraan Masyarakat (PKM) telah berlangsung dengan baik. Hal ini dapat ditunjukkan dari ketercapaian pada target capaian luaran kegiatan PKM . Pemanfaatan alat plate slicer sistem down disk knife ini mampu mengurangi beban pekerjaan manusia serta dapat meningkatkan kecepatan dan kapasitas produksinya. Teknologi tepat guna alat plate slicer ini memiliki kapasitas pengirisan $\pm 100 \mathrm{~kg} / \mathrm{jam}$ atau 20 kali lipat dibandingkan cara tradisional. Alat ini mampu meningkatkan kecepatan produksi dalam pengirisan adonan gelondong kerupuk dan dilengkapi sistem adjustable ketebalan irisan $\pm 0,2 \mathrm{~mm}-2 \mathrm{~mm}$ dengan

$$
\text { Teknologi Tepat Guna }
$$


tiap kenaikan ketebalan 0,2 mm. Dalam kegiatan PKM ini juga dilakukan pelatihan dan penyuluhan cara pemeliharaan alat serta edukasi tentang strategi dan manajemen pemasaran dalam rangka meningkatkan kecepatan produktifitas dan nilai jual produk. Mitra juga sangat kooperatif dalam kegiatan PKM ini dalam mengidentifikasi kebutuhan pengrajin guna pertimbangan dalam rancang bangun alat plate slicer ini.

\section{UCAPAN TERIMAKASIH}

Ucapan terimakasih kami sampaikan kepada Kementerian Riset, Teknologi dan Pendidikan Tinggi Direktorat Jenderal Penguatan dan Pengembangan , Direktorat Riset dan Pengabdian Masyarakat sesuai kontrak Pengabdian Masyarakat, Program Kemitraan Masyarakat (PKM) Nomor : 200AR/WM01.5/N/2019.

\section{REFERENSI}

Apridev Khomenie dan Ema Umilia, (2013), " Arahan Pengembangan Kawasan Wisata Terpadu Kenjeran Surabaya", JURNAL TEKNIK POMITS Vol. 2, No. 1, ISSN: 2337-3539.

Eska Hiola, Evi Sunarti Antu, Yunita Djamalu, (2016), " RANCANG BANGUN ALAT PEMOTONG LONTONG KERUPUK MENGGUNAKAN TALI SENAR" Jurnal Teknologi Pertanian Gorontalo (JTPG) Eska Hiola1), ISSN 2502-485X Volume 1, Nomor 1, Mei 2016.

Hadi Santosa, Martinus Edi, Ardy Wiendarto, (2012), "Alat Bantu Pemotong Kerupuk".

Hadi Santosa, Yuliati, (2010) " Slicer Elektrik Perajang Empon-Empon “.

Hadi Santosa, Yuliati, (2013), " Alat pengering kerupuk dan Ikan berbasis Efek Rumah Kaca”.

Hikmah Purwanti, (2011), " INOVASI PEMBUATAN KERUPUK BAWANG DENGAN SUBSTITUSI TEPUNG KENTANG HITAM".

Nurwachidah Rosiani, Basito, Esti Widowati, (2015), “ KAJIAN KARAKTERISTIK SENSORIS FISIK DAN KIMIA KERUPUK FORTIFIKASI DAGING LIDAH BUAYA (Aloe vera) DENGAN METODE PEMANGGANGAN
MENGGUNAKAN MICROWAVE”, Jurnal Teknologi Hasil Pertanian, Vol. VIII, No. 2, Agustus 2015.

Sugito, Hermanto, Arfah , (2013), "PENGARUH KETEBALAN IRISAN DAN SUHU PENGGORENGAN HAMPA (VAKUM) TERHADAP KARAKTERISTIK KERIPIK LABU KUNING (Cucurbita moschata)", ISSN 2088 5369 Jurnal Agroindustri, Vol. 3 No. 2, November 2013: 83 - 97 .

Sutrisno K, 2009, " PENGOLAHAN ANEKA KERUPUK” Ebookpangan.com. 